УДК $377.091 .36-057.8$

DOI:

Ірина Заблоцька, аспірант кафедри технологічної та професійної освіти Дрогобиџького державного педагогічного університету імені Івана Франка

\title{
НАВЧАЛЬНО-ПРОФЕСІЙНА МОТИВАЦІЯ МАЙБУТНІХ ФАХІВЦІВ ХАРЧОВИХ ТЕХНОЛОГІЙ ЯК ЧИННИК ГОТОВНОСТІ ДО ПРОФЕСІЙНОЇ ДІЯЛЬНОСТІ
}

У статті досліджується проблема взаємозв 'язку навчальної мотивачії майбутніх фахівиів харчових технологій з їх готовністю якісно здійснювати професійні обов'язки. У прочессі дослідження узагальнено існуючі в сучасній літературі підходи до визначення навчально-професійноӥмотивації, на основі анкетування виявлено труднощі, а також виокремлено умови й основні напрями педагогічної підтримки розвитку мотивації учнів закладу професійно-технічної освіти.

Ключові слова: мотиви; навчально-професійна мотивація; фахівці харчових технологій; заклад професійно-технічної освіти.

Табл. 1. Лім. 10.

Iryna Zablotska, Postgraduate Student of the Technological and Professional Education Department, Drohobych Ivan Franko State Pedagogical University

\section{TRAINING AND PROFESSIONAL MOTIVATION OF FUTURE FOOD TECHNOLOGY PROFESSIONALS AS A FACTOR OF READINESS FOR PROFESSIONALACTIVITY}

The article explores the problem of the relationship between the educational motivation of future food professionals and their willingness to perform their professional duties qualitatively. In the course of the research, the approaches in determining modern vocational motivation, existing in modern literature, were summarized, difficulties were identified on the basis of the questionnaire, as well as the conditions and main directions of pedagogical support for the development of motivation of the students of vocational education.

It is revealed that a modern graduate of a vocational education institution should not only possess special knowledge, skills and competences, but also be motivated, feel the need for achievement and success in training and in the workplace, be aware of its demand in the labor market. For this purpose it is important to constantly instill in the students an interest for learning, independent acquisition of professional knowledge and skills, continuous selfeducation in the specialty.

It is determined that vocational motivation is the action of specific motivations that determine the choice of profession and the long-term fulfillment of the duties associated with the profession. It is formed under the influence of external factors of environmental reality (an educational and professional environment) and career guidance.

The conducted research confirms that the state of expression of educational and professional motivation of future food technologists depends on how students adequately evaluate, correlate their educational activities with real opportunities and level of aspirations, as well as on the external influence of educational and professional environment.

Keywords: motives; educational and professional motivation; specialists in food technology; an institution of vocational education.

П остановка проблеми. Зміни, що відбуваються в різних сферах трудової діяльності людини, висувають нові вимоги до організації та якості професійної освіти. У статті 15 Закону України "Про освіту" наголошується, що метою професійної (професійно-технічної) освіти є формування і розвиток професійних компетентностей особи, необхідних для професійної діяльності за певною професією у відповідній галузі, забезпечення іiі конкурентоздатності на ринку праці та мобільності і перспектив кар'єрного зростання впродовж життя [8]. Натомість, у "Концепції реалізації державної політики у сфері професійної (професійно-технічної) освіти “Сучасна професійна (професійно-технічна) освіта" на період до 2027 року” зазначено, що основною проблемою, яка потребує розв'язання, $е$ невідповідність підготовки кваліфікованих кадрів потребам особи, національної економіки та суспільства [4].

Сучасний випускник закладу професійнотехнічної освіти (ЗПТО) повинен не лише володіти спеціальними знаннями, вміннями і навичками, набути професійні компетенції, а й відчувати потребу в досягненнях й успіху на робочому місці, знати про свою затребуваність на ринку праці. Важливо прищеплювати в учнів інтерес до навчання, самостійного здобуття професійних знань й умінь, неперервної самоосвіти з фаху тощо 


\section{НАВЧАЛЬНО-ПРОФЕСІЙНА МОТИВАЦІЯ МАЙБУТНІХ ФАХІВЦІВ ХАРЧОВИХ ТЕХНОЛОГЙ ЯК ЧИННИК ГОТОВНОСТІ ДОПРОФЕСІЙНОЇ ДІЯЛЬНОСТІ}

[7; 9]. Тому система професійно-технічної освіти, постійно розвиваючись й удосконалюючись, вимагає сучасного змісту, інноваційних форм i методів навчання, які відповідають новим стандартам підготовки висококваліфікованих фахівців. У зв'язку з цими змінами проблема професійної мотивації учнів ЗПТО набуває особливого значення.

Аналіз основних досліджень і публікацій. Дослідженню теоретико-методологічних i науково-методичних засад фахової підготовки майбутніх кваліфікованих робітників присвячені праці С. Батишева, О. Вакуленка, Р. Гуревича, О. Коваленко, П. Лузана, В. Манько, Н. Ничкало, В. Радкевич, В. Сидоренка, О. Щербак та ін. У центрі уваги вітчизняних учених постало обгрунтування сучасної методології професійної підготовки кваліфікованих робітників, науковометодичного забезпечення якісного освітнього процесу, організаційно-педагогічних питань оновлення й розвитку системи професійнотехнічної освіти загалом. 3 іншого боку, різні аспекти стимулювання мотивації до навчання досліджували Л. Божович, П. Гончарук, С. Занюк, Є. Ільїн, Г. Костюк, А. Маркова, М. Лук’янова, В. Семиченко й ін. Однак проблема навчальної мотивації майбутніх фахівців харчових технологій й надалі потребує грунтовного вивчення у зв'язку зі зростанням вимог сучасного суспільства до процесу та результатів професійної підготовки у ЗПТО.

Мета статті. Дослідити проблему взаємозв'язку навчальної мотивації майбутніх фахівців харчових технологій з їх готовністю якісно виконувати професійні обов'язки.

Виклад основного матеріалу дослідження. Мотивація є головною рушійною силою у поведінці та діяльності людини, у т. ч. і в процесі фахової підготовки майбутнього спеціаліста у галузі харчових технологій. Звідси, особливо важливими постають питання про стимулювання й мотивацію навчальної діяльності цієї категорії учнів ЗПТО.

Передовсім розглянемо, як мотивація й мотиви трактуються у психології. Необхідно зазначити, що в науці поняття “мотив" i “мотивація” визначаються по-різному, тому й донині не існує загальноприйнятих дефініцій. Зокрема, А. Маслоу визначав цей термін таким чином: мотивація - це спонукання, що викликають активність особистості та визначають ії напрям [6]. Це визначення пов'язує три самостійних види психологічних явищ: по-перше, мотивацію розглядають як привід, котрий активізує особистість для задоволення виникаючих потреб, по-друге, мотивація $є$ причиною вибору певної спрямованості поведінки i, нарешті, по-третє, мотивацію розглядають як засіб самоконтролю людини. Отже, одним із найголовніших понять, пов'язаних з мотивацією є потреби. Будь-яка мотивація грунтується на потребах людини i спрямована на їх задоволення. Всі потреби можна розділити на дві категорії: зовнішні і внутрішні: до перших належать органічні потреби (потреби в їжі, сні тощо), до других - матеріальні, соціальні та духовні (потреба в самореалізації, любові, навчанні тощо) [2]. Наступною ланкою мотивації $\epsilon$ спонукання, тобто поведінковий прояв бажання людини задовольнити свої потреби. Ця поведінка спрямована на мету - досягнення усвідомленого результату, який задовольняється повністю чи частково, або не задовольняється зовсім. Все це дає нам змогу зробити висновок, що мотиви відрізняються один від одного видом потреби, яка в них закладена, формами, які вони приймають, широтою або вузькістю, а також конкретним змістом діяльності, в якій вони реалізуються.

Складним видам діяльності, зазвичай, відповідає не одна, а декілька одночасно діючих і взаємопов'язаних мотивів, що утворюють розгалужену систему мотивації дій та вчинків людини [6]. Освітній процес належить до складних видів діяльності, тому мотивів може бути дуже багато, і вони можуть не лише проявлятися окремо в кожній людині, а й зливатися в єдине ціле, формуючи складні мотиваційні системи. На думку А. Маркової, спрямованість на освітню діяльність, мотиви навчання залежать від смислу учіння, тобто, по-перше, від усвідомлення учнем об'єктивної значущості навчання, яке грунтується на моральних цінностях, прийнятих у соціумі та сім'ї, а, по-друге, від розуміння суб'єктивної значущості навчання для себе, яке обов'язково переломлюється через рівень домагань, самоконтроль і самооцінку навчальної роботи. Звідси, вчена визначає навчальний мотив як “спрямованість учня на різні сторони навчальної діяльності" [5].

Тривалий час проблемі мотивації учнів ЗПТО не приділялося належної уваги, насправді ж, на нашу думку, це один із найбільш ефективних способів вдосконалення освітнього процесу. Переконані, що мотиви є рушійними силами процесу навчання та засвоєння матеріалу, а мотивація до навчання є достатньо непростим і неоднозначним процесом зміни ставлення особистості, як до окремого предмету вивчення, так і освітнього процесу загалом.

Мотиви або, іншими словами, причини, що стимулюють і спонукають учнів до активної діяльності, можуть бути різноманітні. Вчені за 


\section{НАВЧАЛЬНО-ПРОФЕСІЙНА МОТИВАЦІЯ МАЙБУТНІХ ФАХІВЦІВ ХАРЧОВИХ ТЕХНОЛОГІЙ ЯК ЧИННИК ГОТОВНОСТІ ДОПРОФЕСІЙНОЇ ДІЯЛЬНОСТІ}

спрямованістю та змістом виділяють такі види мотивів [3]: 1) соціальні (борг, відповідальність, розуміння значущості навчання для всього суспільства); 2) пізнавальні мотиви (прагнення більше знати з усіх дисциплін, стати ерудованим); 3) професійно-ціннісні (без знань не можливо оволодіти професією); 4) естетичні (від навчання отримуєш задоволення, розкриваєш свої приховані здібності й таланти); 5) комунікативні (можливість розширювати коло спілкування завдяки підвищенню свого інтелектуального рівня та новим знайомствам); 6) статусно-позиційні (прагнення через навчання або громадську діяльність утвердитися в суспільстві, в своєму закладі освіти, навчальній групі тощо); 7) традиційно-історичні (встановлені стереотипи, які виникли в суспільстві та зміцнилися з плином часу); 8) утилітарно-практичні (необхідність в отриманні свідоцтва про освіту, яке дозволяє гарно працевлаштуватися) та ін.

Отже, мотиви - це мобільна система, на яку можна впливати ззовні. Навіть якщо вибір учнем майбутньої професії був зроблений не цілком самостійно та недостатньо усвідомлено, то, цілеспрямовано формуючи стійку систему мотивів діяльності, можна допомогти майбутньому фахівцю в професійній адаптації та професійному становленні. Ретельне вивчення мотивів вибору майбутньої професії дасть можливість коригувати мотиви навчання і впливати на професійне становлення учнів ЗПТО.

Ефективність освітнього процесу безпосередньо пов'язана з тим, наскільки високою $\epsilon$ мотивація і високим стимул оволодіння майбутньою професією [10]. Саме готовність учня - майбутнього фахівця харчових технологій - до розв'язання професійних завдань $є$ метою професійно-технічної освіти. Отже, в сучасних психолого-педагогічних дослідженнях під навчально-професійною мотивацією розуміється дія конкретних спонукань, які зумовлюють вибір професії та тривале виконання обов'язків, пов'язаних з цією професією. Навчальнопрофесійна мотивація формується під впливом чинників навколишньої дійсності та профорієнтаційної роботи.

Проблемі мотивації учнів у різних галузях діяльності присвячена велика кількість наукових досліджень, однак проблема розвитку готовності учня до майбутньої професійної діяльності через організацію цього процесу в ЗПТО недостатньо розроблена. Нами здійснене дослідження 3 виявлення навчально-професійної мотивації майбутніх фахівців харчових технологій. Відомо, що діагностика мотиваційної сфери є доволі складним завданням, адже мотиви діяльності та поведінки, утворюючи ядро особистості, $\epsilon$ найбільш “закритою зоною” [6]. Ми виходили 3 того, що ефективність і результативність освітнього процесу в ЗПТО визначається складною системою мотивів учнів, що грунтуються на основі їхніх потреб, бажань та інтересів.

3 метою дослідження навчально-професійної мотивації методом анкетування у 2016 - 2018 роках було проведено опитування учнів, які оволодівають робітничими професіями "Кухар; кондитер" та “Офіціант; кухар” на основі базової (2 роки 10 місяців) і повної (1 рік 5 місяців) загальної середньої освіти та отримують освітньокваліфікаційний рівень “Молодший спеціаліст” зі спеціальності “Харчові технології” на базі повної загальної середньої освіти та робітничої кваліфікації у Державному навчальному закладі “Вище професійне училище №34 м. Стрий”. В анкеті було виділено такі групи чинників: привабливість обраної професії, вибір закладу професійно-технічного освіти, кар'єрне зростання, прагнення до досягнень та самовдосконалення, соціальні контакти. Всього в опитуванні брало участь 224 учнів молодших і старших курсів та випускників ОКР “Молодший спеціаліст”. Статистичні дані, отримані на основі відповідей учнів на питання анкети, подані в таблиці 1.

Аналіз отриманих результатів дозволяє зробити такі висновки:

1) у середньому лише близько чверті учнів обирають напрям професійної підготовки усвідомлено, інші - за порадою батьків, родичів і друзів;

2) до старших курсів на ОКР “Молодший спеціаліст" частка учнів, не впевнених у правильності вибору майбутньої професії, збільшується;

3) невпевненість у правильності вибору майбутньої професії у частині студентів пов'язана з незнанням іiі переваг і можливостей творчої реалізації;

4) позитивним $\epsilon$ те, що частина учнів сподівається в межах майбутньої професії приносити користь людям;

5) має місце тенденція до збільшення частки учнів, які мріють стати керівниками закладів громадського харчування, отримати Зірку Мішлена і бажають отримувати високу зарплату.

6) необхідність отримання робітничої спеціальності, первинну роботу 3 невисокими зарплатами усвідомлює незначна частина учнів;

7) лише частина учнів для підвищення професійної кваліфікації усвідомлює необхідність 
Результати опитування майбутніх фахівців харчових технологій з метою визначення навчально-професійної мотивації (\% від загального кількості опитаних)

\begin{tabular}{|c|c|c|c|}
\hline \multirow{2}{*}{$\begin{array}{l}\text { № } \\
\text { 3/II }\end{array}$} & \multirow[t]{2}{*}{ Питання анкети } & \multicolumn{2}{|c|}{ Відповіді } \\
\hline & & $\begin{array}{l}\text { Кваліф. } \\
\text { робітники }\end{array}$ & $\begin{array}{c}\text { Молодші } \\
\text { спеціалісти }\end{array}$ \\
\hline \multirow[t]{4}{*}{1.} & \multicolumn{3}{|l|}{ Чи подобається Вам обрана професія? } \\
\hline & Так & 76 & 68 \\
\hline & $\mathrm{Hi}$ & 6 & 11 \\
\hline & Важко відповісти & 18 & 21 \\
\hline \multirow[t]{6}{*}{2.} & \multicolumn{3}{|l|}{ Що Вас приваблює в обраній професії? } \\
\hline & Можливість творчої реалізації & 36 & 14 \\
\hline & Можливість отримувати високу зарплату & 29 & 28 \\
\hline & Можливість робити корисне для людей & 18 & 20 \\
\hline & Ще не визначився & 15 & 26 \\
\hline & Нічого & 2 & 2 \\
\hline \multirow[t]{5}{*}{3.} & \multicolumn{3}{|l|}{ Чим зумовлений Ваш вибір закладу професійно-технічної освіти? } \\
\hline & Бажання отримати професію за обраною спеціальністю & 24 & 25 \\
\hline & Близьке розташування ЗПТО від місця проживання & 15 & 18 \\
\hline & За порадою друзів і знайомих & 25 & 27 \\
\hline & За порадою (вимогою) батьків і родичів & 36 & 30 \\
\hline \multirow[t]{5}{*}{4.} & \multicolumn{3}{|l|}{ Яку кінцеву кар 'єрну мету Ви ставите? } \\
\hline & $\begin{array}{l}\text { Мрію стати майстер-шефом, керівником закладу громадського } \\
\text { харчування }\end{array}$ & 24 & 59 \\
\hline & Отримати Зірку Мішлена & 21 & 22 \\
\hline & Цілком був би задоволений робітничою посадою & 46 & 13 \\
\hline & Не визначився & 9 & 6 \\
\hline \multirow[t]{6}{*}{5.} & \multicolumn{3}{|l|}{ Що Ви робите для досягнення поставленої мети? } \\
\hline & Намагаюся добре вчитися & 46 & 34 \\
\hline & $\begin{array}{l}\text { Додатково вивчаю } \\
\text { професійних сайтів }\end{array}$ & 12 & 8 \\
\hline & Відвідую майстер-класи провідних фахівців-практиків & 9 & 15 \\
\hline & Працюю у позаурочний час і вчуся у кращих фахівців & 14 & 36 \\
\hline & Поки нічого не роблю & 19 & 7 \\
\hline
\end{tabular}

додаткових зусиль у вигляді участі в професійних конкурсах, вивчення додаткової фахової літератури і сайтів, відвідування майстер-класів тощо;

8) поступово збільшується кількість учнів, які працюю у позаурочний час і вчаться у кращих фахівців на своїх робочих місцях.

Крім цього, нами вивчалася мотивація майбутніх фахівців харчових технологій 3 використанням "Методики визначення мотивації професійного навчання” [1, 210 - 213]. В опитуванні брало участь 132 учня, які навчалися на 1 - 2 курсах за робітничими професіями "Кухар; кондитер” та “Офіціант; кухар”, а також 92 особи, які здобували спеціальність "Харчові технології” на ОКР “Молодший спеціаліст”. Учням пропонувалося 44 питання, 3 яких: $24-$ передбачали виявлення рівня свідомого ставлення до проблем навчання (вольова сфера), 20 - емоційного фізіологічного сприйняття різних видів діяльності в мінливих ситуаціях (емоційна сфера). 


\section{НАВЧАЛЬНО-ПРОФЕСІЙНА МОТИВАЦІЯ МАЙБУТНІХ ФАХІВЦІВ ХАРЧОВИХ ТЕХНОЛОГІЙ ЯК ЧИННИК ГОТОВНОСТІ ДОПРОФЕСІЙНОЇ ДІЯЛЬНОСТІ}

Результати опитування засвідчили, що з-поміж учнів 1 - 2 курсів, які здобувають робітничі спеціальності, у 34 осіб (26 \%) виявлено високий рівень мотивації, у 54 (41\%) - середній рівень мотивації, у 44 (33 \%) - низький рівень мотивації.

Дані засвідчують, що більшість учнів молодших курсів (41\%) мають середній рівень мотивації. До процесу навчання вони здебільшого ставляться індиферентно: у кращому випадку проявляють пізнавальну активність на рівні попередження претензій з боку викладачів, майстрів виробничого навчання, адміністрації ЗПТО, у гіршому - займаються пошуком шляху заміни матеріальним еквівалентом власного прояву знань й умінь. Частина учнів стурбована проведенням власного дозвілля, який домінує в розподілі часу.

Високий рівень мотивації учнів молодших курсів (26\%) проявляється в таких характеристиках: спрямованість на навчальнопрофесійну діяльність, розвиток самоосвіти та самопізнання. Вони, зазвичай, ретельно планують своє життя, ставлячи конкретні цілі. Їм характерна висока потреба в збереженні власної індивідуальності, прагненні до незалежності від інших та бажанні зберегти неповторність, своєрідність власної особистості, своїх поглядів і переконань, стилю життя. Учні прагнуть досягнути відчутних і конкретних результатів в будь-якому виді діяльності, зокрема і в навчальній. Вони виявляють здатність до співпереживання, етичного ставлення до людей, самого себе, природи, професії, а також до засвоєння традиційних ролей, норм, правил поведінки в суспільстві та професійному середовищі.

Слід зазначити, що учні з низьким рівнем мотивації складають третину від загальної кількості. Для цієї групи учнів професійна сфера ще немає того значення, як сфери навчання i захоплень. Учні рідко замислюються про свій завтрашній день, професійне життя для них $є$ ефемерним, непривабливим, невідомим. Їх влаштовує звичне, безтурботне життя, в якому навчання професії “змагається” з улюбленими заняттями й уподобаннями. Майбутні професійні плани не мають реальної опори в сьогоденні та не підкріплені особистою відповідальністю за їх реалізацію. Це пов'язано, на нашу думку, з тим, що учні ще знаходяться на стадії професійного самовизначення.

3-поміж учнів, які здобувають спеціальність “Харчові технологіі” на ОКР “Молодший спеціаліст”, були виявлені такі результати: у 44 студентів (48 \%) -високий, у 32 студентів (35\%)
- середній та в 16 студентів (17\%) - низький рівень мотивації.

Результати дослідження показують, що більшість майбутніх молодших спеціалістів (48 \%) мають високий рівень мотивації. Психологічна інтерпретація результатів підтверджує соціальну стійкість випускників спеціальності “Харчові технології, їх професійну цілеспрямованість, бажання освоїти як основну, так і додаткову професію. Це особливо стосується тих учнів, які проходили виробничу практику у популярних закладах громадського харчування або працюють у позаурочний час.

Висновки. Вивчення рівнів мотивації професійного навчання учнів ЗПТО показав, що для зниження кількості “випадкових” в професії кухар, кондитер, фахівець харчових технологій необхідна організація не лише профорієнтаційної роботи серед школярів, а й розроблення комплексної системи тестування майбутніх спеціалістів на професійну придатність.

Упродовж усього періоду навчання одним із завдань ЗПТО має стати психологічна допомога учням у підготовці до майбутніх професійних труднощів. Для цього необхідно проводити зустрічі з кращими випускниками, провідними фахівцями галузі громадського харчування, які розповідатимуть про власні досягнення та пояснюватимуть як досягнути успіху в професії. Для реалізації творчого потенціалу учнів, підвищення їхнього інтересу до професії необхідно проведення провідними фахівцями на базі ЗПТО майстер-класів, тренінгів професійних конкурсів, семінарів і конференцій за професійним спрямуванням.

Учні мають усвідомити, що на сучасному виробництві будуть затребувані лише ті, хто систематично займається підвищенням своєї професійної майстерності, старанно вчиться, додатково займається самоосвітою, постійно перевіряє свої знання на практиці. Для цього повинна бути створена система взаємодії ЗПТО 3 підприємствами галузі громадського харчування, яка дозволяє активно заохочувати тих учнів, які не пропускають заняття, активно здобувають знання і набувають навички на теоретичних і практичних заняттях, активно займалися дослідницькою роботою, беруть участь у професійних конкурсах, олімпіадах, змаганнях тощо. За період навчання на кожного учня повинно бути складено портфоліо, в створенні якого необхідна участь не лише викладачів, майстрів виробничого навчання, а й фахівців закладів громадського харчування, на базі яких учні проходили практику, працювали у позаурочний час. 

ЯК ЧИННИК ГОТОВНОСТІ ДО ПРОФЕСІЙНОЇ ДІЯЛЬНОСТІ

Таким чином, результати дослідження показують, що на кожному курсі та освітньокваліфікаційному рівні зустрічаються учні 3 різними рівнями мотивації-високим, середнім і низьким. Це свідчить, що стан вияву навчальнопрофесійної мотивації залежить від того, як адекватно оцінює, співвідносить учень свою навчальну діяльність із реальними можливостями та рівнем домагань, а також від зовнішнього впливу, створеного освітнім середовищем ЗПТО.

\section{ЛІТЕРАТУРА}

1. Бурковська 3. Є. Тенденції розвитку професійних цінностей майбутніх фахівців аграрного профілю (кінець XX - початок XXI століття) : дис. ... канд. пед. наук : 13.00.01. Дрогобич, 2014. 253 с.

2. Занюк С.С. Психологія мотивації: навч. посіб. Київ, 2002. 304 с.

3. Ильин Е.П. Мотивация и мотивы. СанктПетербург, 2002. 512 с.

4. Концепція реалізації державної політики у сфері професійної (професійно-технічної) освіти “Сучасна професійна (професійно-технічна) освіта” на період до 2027 року: Розпорядження Кабінету Міністрів України від 12.06.2019 р. № 419 p. URL : https://zakon.rada.gov. ua/laws/show/ 419-2019-p\#n8. (дата звернення: 18.06.2019).

5. Маркова А.К. Формирование мотивации учения в школьном возрасте: пособ. Москва, $1983.96 \mathrm{c}$.

6. Маслоу А. Мотивация и личность. СанктПетербург, 1999. 512 с.

7. Ничкало Н. Г. Розвиток професійної освіти в умовах глобалізаційних та інтеграційних процесів: монографія. Київ : Видавництво НПУ імені М. П. Драгоманова, 2014. 125 с.

8. Про освіту : Закон України від э05.09.2017 № 2145-VIII. Дата оновлення : 09.08.2019. URL: https://zakon.rada.gov.ua/laws/show/2145-19 (дата звернення: 06.09.2019).

9. Радкевич В. О. Професійна освіта і навчання для сталого розвитку суспільства. Професійнотехнічна освіта. 2015. № 4 (69). С. 7-11.

10. Стародубцева В. К. Мотивация студентов к обучению. Современные проблемы науки и образования. 2014. № 6. URL: http:// www.science-education.ru/ru/article/view?id=15617/ (дата звернення: 06.09.2019).

\section{REFERENCES}

1. Burkovska, Z. Ye. (2014). Tendentsii rozvytku profesiinykh tsinnostei maibutnikh fakhivtsiv ahrarnoho profiliu (kinets $X X$ - pochatok XXI stolittia) [Trends in the development of professional values of future specialists of agrarian profile (end of XX - beginning of XXI century)]. Drohobych, $253 \mathrm{p}$. [in Ukrainian].

2. Zaniuk, S. S. (2002). Psykholohiia motyvatsii [Psychology of motivation]. Kyiv, 304 p. [in Ukrainian].

3. Ilin, E.P. (2002). Motivatsiya $i$ motivyi [Motivation and motives]. Sankt-Peterburh, 512 p. [in Russian].

4. Kontseptsiia realizatsii derzhavnoi polityky u sferi profesiinoi (profesiino-tekhnichnoi) osvity "Suchasna profesiina (profesiinotekhnichna) osvita" na period do 2027 roku [The concept of state policy in the field of vocational (vocational-technical) education "Modern vocational (vocational-technical) education" for the period up to 2027]: Rozporiadzhennia Kabinetu Ministriv Ukrainy vid 12.06.2019 r. № 419 r. Available at: https://zakon.rada.gov. ua/laws/show/ 419-2019-r\#n8. (accessed 18 June 2019). [in Ukrainian].

5. Markova, A. K. (1983). Formyrovanye motyvatsyy uchenyia $v$ shkolnom vozraste [Formation of motivation for learning at school age]. Moscov, 96 p. [in Russian].

6. Maslou, A. (1999). Motyvatsyia i lychnost [Motivation and personality]. Sankt-Peterburh, 512 p. [in Russian].

7. Nychkalo, N. H. (2014). Rozvytok profesiinoi osvity $v$ umovakh hlobalizatsiinykh ta intehratsiinykh protsesiv [Development of vocational education in the context of globalization and integration processes]. Kyiv, 125 p. [in Ukrainian].

8. Pro osvitu : Zakon Ukrainy vid э05.09.2017 № 2145-VIII. [On education: Law of Ukraine dated 05.09.2017 № 2145-VIII]. Available at: https:// zakon.rada.gov. ua/laws/show/2145-19. [in Ukrainian].

9. Radkevych, V. O. (2015). Profesiina osvita $i$ navchannia dlia staloho rozvytku suspilstva [Vocational education and training for the sustainable development of society]. Vocational and technical education. № 4 (69). pp. 7-11. [in Ukrainian].

10. Starodubtseva, V. K. (2014). Motyvatsyia studentov $k$ obuchenyiu [Students motivation for learning]. Sovremennye problemy nauky i obrazovanyia. No. 6. Available at: http:// www.science-education.ru/ru/article/view?id=15617. [in Russian].

Стаття надійшла до редакції 18.09.2019 